\title{
Energy Productivity and Efficiency of Lowland Rice (Var. PSB Rc18) Under Various Organic Nutrient Sources and Quantum Enhancers
}

\author{
Berta C. Ratilla' and Teodoro C. Mendoza ${ }^{2}$ \\ ${ }^{1}$ Department of Agronomy, Visayas State University, \\ Visca, Baybay City, Leyte 6521-A Philippines; \\ ${ }^{2}$ Crop Science Cluster, College of Agriculture, University of the Philippines \\ Los Baños, College Laguna, Philippines
}

ABSTRACT

Energy analysis is not usually given much emphasis in crop production despite the latter's huge dependence on oil and fuel. This study was conducted for two cropping seasons to assess whether the use of various nutrient sources can increase yield, energy productivity, and use efficiency of lowland rice (PSB Rc18). All production inputs and activities were accounted and energy analysis was done using energy coefficients adopted by previous researchers. Parameters on grain yield, energy expenditures, energy productivity, efficiency, and intensity were taken. Rice applied with organic fertilizer from unenhanced composted cow manure (UECM) yielded significantly higher by $61 \%$ and $18 \%$ than the untreated control and the full inorganic treatment, respectively. Quantum and organic nutrient sources spent 69.18-71.79 liter diesel oil equivalent (LDOE) ha $^{-1}$ which is 2-3 times lesser than the use of sole inorganic or combined with organic nutrient sources (142.13-225.74 LDOE ha ${ }^{-1}$ ), thus giving significantly higher energy productivity and efficiency. Unenhanced composted cow manure was the most productive and efficient in terms of energy use by 1.59 and 3.73 times over the control and full inorganic treatment, respectively. Energy spent to produce a ton of unmilled rice was markedly reduced by $53 \%$ from organic fertilization due to lower energy intensities (15.95-25.16 $\mathrm{LDOE} \mathrm{t}^{-1}$ grain) than inorganic treatments (36.50-60.89 LDOE $\mathrm{t}^{-1}$ grain). Hence, at this time of energy crisis and climate change, organic farming which includes use of quantum enhancers is a potential option in improving energy resource effectiveness of PSB Rc18.

Keywords: energy expenditure, productivity, efficiency and intensity, organic farming, and quantum enhancers

\section{INTRODUCTION}

The unstable energy cost really affects the current food production system. This is because most if not all of the field management operation and practices rely greatly on the use of fuel and oil. However, energy analysis is not given much emphasis in most crop production systems. Rahman and Barmon (2012) stressed the great importance of energy analysis in crop production since energy is being 
utilized not only in farm machineries, human or draft animal power, electricity and diesel but also in the manufacture of fertilizers and pesticides. Rice production in particular is not an exception. It involves several energy spending activities that production techniques, which are resource efficient and with less energy expenditures, need to be looked into.

Organic, diversified and integrated farming systems (Mendoza, 2008), or with sustainable agricultural movement (Perlas, 1993 and Zamora, 1996), time tested approaches (Fernandez, 2000 and 2001) such as biodynamic farming, agnihotra among others are some ways to minimize cost and improve energy efficiency. This can also be done by reducing or eliminating the oil-base energy inputs in the production activities. The use of quantum enhancers such as BD 500 or Agnihotra ash is known to have a wide range of impact and multi dimensional effects (Steiner, 2005 and Wildfeuer, 2006). Even if it is applied at a very small amount, the mechanism lies more on the realm of subtle energy, where a close alignment of the non-physical world with physical reality exists (Perlas 1993, Dimaporo and Fernandez 2007). Accordingly, it acts fast even with a very small amount of substance applied. Variable results have been obtained with the effects of biodynamic preparations but in some they stimulated life both in soil and plants by improving soil quality, but lowering yield with greater net income than their conventional counterparts. On the other hand, agnihotra ash has positive energies that destroy negative energies thus help purify the atmosphere.

Growing rice with less input on energy, chemical fertilizer or through organic/alternative approaches coupled with appropriate management strategies may enhance yield and productivity without harming the environment. Mendoza (2010) stressed the importance of ecologically sound and organic-chemical-free production practices as they will not only restore degraded soil and prevent environmental pollution from greenhouse gases but also lessen farmers' financial burden in adopting oil-dependent production venture. Often the conventional production system spent higher overall energy input than the organic production system due to its heavy reliance on energy intensive fertilizers and chemicals (Ziesemer 2007; Kaltsas et al., 2007). In plantation crops, organic farming indicated lower energy consumption thus improved energy productivity and efficiency as well as lessened greenhouse gas emission than the conventional practice (Gundogmos 2006, Ziesemer 2007, Kaltsas et al., 2007 and Kavargiris et al., 2009). In sugarcane, Egle and Mendoza (2013) found that farm inputs accounted $42 \%$ of the total energy costs with urea getting the highest expenditure (93.7\%). They found highest energy efficiency (6.87) when no $\mathrm{N}$ fertilizer was applied while lowest (4.21) when $\mathrm{N}$ fertilizer was applied at $300 \mathrm{~kg} \mathrm{ha}^{-1}+\mathrm{Bio}-\mathrm{N} \AA$. In lowland rice, Bockari-Gevao (2005) in his study on different tillage systems also found that the total energy inputs spent excluding irrigation energy was $12,225,97 \mathrm{MJ} \mathrm{ha}^{-1}$ with fertilizer and fuel use as the greatest energy consumer ha ${ }^{-1}$ amounting to $63.2 \%$ and $22.2 \%$, respectively. While Hering (2006) reported a specific energy used by paddy rice at $5.87 \mathrm{MJ} \mathrm{kg}^{-1}$, Nassiri and Singh (2009) likewise found electricity, fertilizer, and chemicals to constitute $72.8 \%$ of the total energy inputs. However, from production to the supermarket, Blengini and Busto (2009) stated that for a $\mathrm{kg}$ of white milled rice, it consumed $17.8 \mathrm{MJ}$ of energy and $4.9 \mathrm{~m}^{3}$ of water and emitted $2.9 \mathrm{~kg}$ of $\mathrm{CO}_{2}$. 
This concern is getting more relevant in the Philippines being beset with climatic changes and instability of fuel prices which usually goes up than down. As a limited resource, the use of fossil energy must be efficiently used if not conserved to minimize $\mathrm{CO}_{2}$ emission. Ziesemer (2007) stated that with low energy inputs as in organic systems, it has less green house gas emission but with greater potential to sequester carbon in biomass than in conventional systems. Effective energy use thereby leads to a sustainable crop production as this implied financial savings, preserved fossil resources, and reduced air pollution (Banaeian et al., 2010). There is a need to assess the yield, energy use, intensity, productivity, and efficiency of growing lowland rice (PSB Rc18) with various nutrient applications, hence this study.

\section{MATERIALS AND METHODS}

\section{Soil Sampling and Analysis}

Composite soil samples were taken from the experimental area prior to land preparation at a depth of $0-20 \mathrm{~cm}$. These were processed and analyzed at the Soils Research Testing and Plant Analysis Laboratory (SRTPAL) of the Dept. of Agronomy and Soil Science and at Central Analytical Services Laboratory (CASL), VSU, Visca, Baybay, Leyte for soil $\mathrm{pH}$, organic matter, total $\mathrm{N}$, extractable $\mathrm{P}$, and exchangeable K. Another set of soil samples were collected from each treatment plot every after harvest for the analysis of the aforementioned parameters. The experimental site had a $\mathrm{pH}$ of 5.53,3.30\% OM, $0.22 \% \mathrm{~N}, 2.46$ and $199.35 \mathrm{mg} \mathrm{kg}^{-1}$, extractable $\mathrm{P}$ and exchangeable $\mathrm{K}$, respectively. This soil is strongly acidic, has medium amounts of organic matter, available $\mathrm{N}$, and exchangeable potassium but with very low extractable P (Landon, 1991).

\section{ExperimentalDesign and Treatments}

The experiment was conducted for two cropping seasons in Bryg. Pangasugan, Baybay City,Leyte. It was laid out in Randomized Complete Block Design (RCBD) with three replications with plots measuring $3.75 \mathrm{~m}$ x $5 \mathrm{~m}$ and with $1.0 \mathrm{~m}$ alleyway between replications and treatment plots. The nutrient sources and time of application of the various treatments are shown in Table 1.

Chemical fertilizers such as urea $(45 \% \mathrm{~N})$, solophos $\left(20 \% \mathrm{P}_{2} \mathrm{O}_{5}\right)$, and muriate of potash $\left(60 \% \mathrm{~K}_{2} \mathrm{O}\right)$ were used in $\mathrm{T}_{2}, \mathrm{~T}_{3}, \mathrm{~T}_{4}$, and $\mathrm{T}_{5}$ where all of the $\mathrm{P}, 1 / 2$ of $\mathrm{K}$ and $1 / 3$ of $\mathrm{N}$ were applied prior to transplanting while the remaining amount of $\mathrm{N}$ was equally sidedressed one month after transplanting and at panicle initiation. For cow manure (unenhanced composted or enhanced composted), the actual amount applied was based on dry weight basis at 5 tons $\mathrm{ha}^{-1}$ and incorporated into the specified plots two weeks before transplanting. While cow manure was procured at the same time, unenhanced composting implied that the material just underwent natural composting for 3 weeks while composting in $\mathrm{T}_{7}, \mathrm{~T}_{8}$ and $\mathrm{T}_{9}$ was enhanced by sprinkling indigenous microorganism (IMO) at the rate of $1 \mathrm{~L}$ in $50 \mathrm{~L}$ water per $1000 \mathrm{~kg}$ cow manure, mixed or turned weekly and allowed to decompose for three weeks. After this period, the enhanced composted materials were already decomposed thus easy to handle while the unenhanced ones were not yet fully decomposed and still had foul odor. 
Table 1. Treatment description and time of application.

\begin{tabular}{|c|c|c|}
\hline Treatments & Description & Time Of Application \\
\hline $\mathrm{T}_{1}$ & Control (no fertilizer applied) & \\
\hline $\mathrm{T}_{2}$ & $\begin{array}{l}\text { Full rate chemical fertilizer } \\
\left(70-60-30 \mathrm{~kg} \mathrm{~N}, \mathrm{P}_{2} \mathrm{O}_{5}, \mathrm{~K}_{2} \mathrm{O} \mathrm{ha}^{-1}\right)\end{array}$ & $\begin{array}{l}\text { Applied before transplanting, at } 1 \text { month } \\
\text { after transplanting and at panicle initiation }\end{array}$ \\
\hline $\mathrm{T}_{3}$ & $\begin{array}{l}\text { Half rate chemical fertilizer }(35-30- \\
15 \mathrm{~kg} \mathrm{~N}, \mathrm{P}_{2} \mathrm{O}_{5} \text { and } \mathrm{K}_{2} \mathrm{O} \mathrm{ha}^{-1}+5 \mathrm{t} \\
\text { ha }^{-1} \text { Composted cow manure }(\mathrm{CCM})\end{array}$ & $\begin{array}{l}\text { Inorganic fertilizer applied similar to } \mathrm{T}_{2} \\
\text { while CCM was applied } 2 \text { weeks before } \\
\text { transplanting }\end{array}$ \\
\hline $\mathrm{T}_{4}$ & 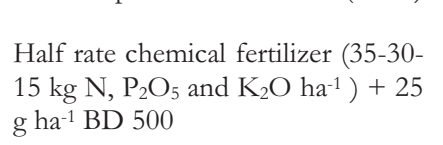 & $\begin{array}{l}\text { Inorganic fertilizer applied similarly to } \mathrm{T}_{2} \\
\text { while Biodynamic (BD) } 500 \text { applied at } \\
\text { transplanting and seedlings were dipped in } \\
\text { BD } 500 \text { solution before transplanting }\end{array}$ \\
\hline $\mathrm{T}_{5}$ & $\begin{array}{l}\text { Half rate chemical fertilizer } \\
\left(35-30-15{\mathrm{~kg} \mathrm{~N}, \mathrm{P}_{2} \mathrm{O}_{5} \text { and } \mathrm{K}_{2} \mathrm{O} \mathrm{ha}}^{-1}\right. \\
)+30 \mathrm{~g} \mathrm{ha}^{-1} \text { Agnihotra ash (Aash) }\end{array}$ & $\begin{array}{l}\text { Inorganic fertilizer applied similar to } \mathrm{T}_{2} \\
\text { while Aash at transplanting }\end{array}$ \\
\hline $\mathrm{T}_{6}$ & $\begin{array}{l}5 \mathrm{t} \mathrm{ha}^{-1} \text { unenhanced composted cow } \\
\text { manure (UECCM) for } 3 \text { weeks }\end{array}$ & 2 weeks before transplanting \\
\hline $\mathrm{T}_{7}$ & $\begin{array}{l}5 \mathrm{t} \mathrm{ha}^{-1} \text { enhanced composted cow } \\
\text { manure (ECCM) }\end{array}$ & 2 weeks before transplanting \\
\hline $\mathrm{T}_{8}$ & $5 \mathrm{t} \mathrm{ha}^{-1} \mathrm{ECCM}+25 \mathrm{~g} \mathrm{ha}^{-1} \mathrm{BD} 500$ & $\begin{array}{l}\text { ECCM was applied } 2 \text { weeks before } \\
\text { transplanting; BD } 500 \text { applied at } \\
\text { transplanting and seedlings were dipped to } \\
\text { BD } 500 \text { solution before transplanting }\end{array}$ \\
\hline $\mathrm{T}_{9}$ & $\begin{array}{l}5 \mathrm{t} \mathrm{ha}^{-1} \mathrm{ECCM}+30 \mathrm{~g} \mathrm{ha}^{-1} \text { Agnihotra } \\
\text { ash (Aash) }\end{array}$ & $\begin{array}{l}\text { CCM applied } 2 \text { weeks before } \\
\text { transplanting;Aash at transplanting }\end{array}$ \\
\hline $\mathrm{T}_{10}$ & $\begin{array}{l}4 \mathrm{~L} \mathrm{ha}^{-1} \text { Indigenous microorganism } \\
\text { (IMO) }\end{array}$ & At final land preparation \\
\hline $\mathrm{T}_{11}$ & $25 \mathrm{~g} \mathrm{ha}^{-1}$ BD 500 alone & $\begin{array}{l}\text { Prior to transplanting and seedlings were } \\
\text { dipped to BD } 500 \text { solution before } \\
\text { transplanting }\end{array}$ \\
\hline $\mathrm{T}_{12}$ & $30 \mathrm{~g} \mathrm{ha}^{-1}$ Agnihotra ash alone & $\begin{array}{l}\text { Prior to transplanting, } 15 \text { and } 30 \text { days after } \\
\text { transplanting }\end{array}$ \\
\hline
\end{tabular}

BD 500 and Agnihotra ash were considered quantum enhancers. These were applied at very small quantity since both were expected to have fast, wide range and multi dimensional effects being part of a science based on life forces (Steiner 2005, Wildfeuer 2006). BD 500 is one preparation of biodynamic farming obtained from Don Bosco Youth Center, Makilala, North Cotabato. This was derived from cow dung placed inside a cow horn and buried under the soil for 6 months. Previous research results showed that some preparation promoted soil quality by improving soil microbial properties and crop root growth. Lower yield was obtained but in terms of profitability it is equal or higher than the conventional practice (Reganold 1995; Jayasree and George 2006). On the other hand, Agnihotra ash was obtained by burning dried cow dung and ghee (unsalted clarified butter) plus brown rice grains in a copper pyramid while the mantra was sung during exact sunrise or sunset time. Prior to application, both quantum 
enhancers were separately stirred vigorously in water to form a deep vortex for 5 minutes, reversed and repeated 4 times for 20 minutes. The potentized solution was sprayed once into the soil prior to transplanting (Valdez and Fernandez 2008; Don Bosco Youth Center, Inc. Undated) while the potentized ash was allowed to stand for 3 days (Angeles, 2008) before spraying. Rice seedlings in the BD 500 treatments were also dipped in BD 500 solution before transplanting. This preparation as a product of Homa therapy will help clean polluted atmosphere due to its positive energy (Paranjpe, 2010). Indigenous Microorganism (IMO) was prepared from cooked rice which was allowed to develop molds under a shady place for three days then fermented with sugar at 1:1 ratio for 1 week and filtered. The filtrate was mixed in a desired quantity of water at the rate of $4 \mathrm{~L} \mathrm{ha}^{-1}$ and sprayed to the soil during final land preparation.

\section{Seedbed Preparation and Transplanting}

Rice seedlings were raised following a modified dapog method where pregerminated seeds of PSB Rc18 were sown in a winow lined with banana leaves and placed with about an inch of topsoil. Seedlings were allowed to germinate and were transplanted 12 days after sowing at 2 seedlings hill ${ }^{-1}$ at a distance of $25 \mathrm{~cm}$ x $25 \mathrm{~cm}$. Missing hills were replanted 5 days after transplanting. The newly transplanted area was drained with water for 3 days to minimize golden apple snail infestation.

\section{Care and Management}

Irrigation water was applied four days after transplanting and was maintained to a depth of 2-3 cm thereafter until two weeks prior to harvest. Golden snail was controlled by releasing ducks one week before transplanting and by handpicking thereafter. Rotary weeding was done 10 days after transplanting and two weeks thereafter. Weeds within the hill were removed by handweeding. Rice plants were sprayed with fresh milk and honey $(400 \mathrm{~mL}$ carabao fresh milk and $150 \mathrm{~mL}$ honey $\mathrm{ha}^{-1}$ ) at 10 days interval between the vegetative to heading stages. This preparation was known to help increase natural enemies of insects and relieve stress of plants (Valdez and Fernandez, 2008; Don Bosco Diocesan Youth Center, Inc.; undated).

BD 508 which was derived from fresh silica-rich horsetail was sprayed three times during the vegetative phase to prevent fungal diseases as well as tungro infection. Fresh horsetail at the rate of 4 cups ha $^{-1}$ was cut into smaller pieces, pounded and soaked overnight in water prior to its application. For the full chemical treatment $\left(\mathrm{T}_{2}\right)$, Karate (50 g L Lambda cyhalotrin) was sprayed at 14 days after transplanting and at 10 -day interval during the entire vegetative phase and at heading stages at the rate of 2 tbsp per $16 \mathrm{~L}$ water.

\section{Harvesting}

This was done when $90 \%$ of the grains in the panicles had ripened. The grains were threshed, cleaned and sundried to 14\% MC before weighing. 


\section{Energy Accounting}

The procedures in energy analysis and the energy coefficients of the materials used and activities done were based from the handbook of Pimentel (1980) and from relevant literatures of Mendoza (2007), Mendoza and Samson (2002), and that one adopted by Bocari-Gevao (2005) and Egle and Mendoza (2013). All production inputs such as fuel, fertilizers, pesticides, seeds, etc. were recorded and all activities from land preparation to harvesting and post harvest operation such as threshing and drying were properly accounted.

The specific energy used (e.g. for fuel) per hectare for a specific field operation was computed by multiplying the average fuel use by its energy coefficient as follows:

$$
\mathrm{DE}=\mathrm{AFU} \times \mathrm{EC}
$$

where:

$\mathrm{DE}=$ Specific direct energy use (fuel) for a field operation, mcal ha $^{-1}$

AFU $=$ Average fuel use per working hour, $1 \mathrm{ha}^{-1}$

$\mathrm{EC}=$ Specific energy value per liter of fuel, $\mathrm{Mcall}^{-1}$

For machinery, this equation was the basis (Moerschner and Gerowitt 2000 as cited by Bochari-Gevao et al., 2005):

where:

$$
\mathrm{EID}=\mathrm{TW} \times \frac{\mathrm{EC}}{\mathrm{LS}} \times \mathrm{h} \times \mathrm{RU}
$$

EID = specific indirect energy for machinery use for a field operation, Mcal ha ${ }^{-1}$

TW = total weight of the specific machine, $\mathrm{kg}$

$\mathrm{EC}=$ energy coefficient of a specific machinery, $\mathrm{Mcal} \mathrm{kg}^{-1}$

LS = life span of machinery

$\mathrm{h}=$ number of hours in operation

$\mathrm{RU}=$ number of runs

The indirect energy per unit area for production inputs such as fertilizers, seeds, and other materials was expressed as:

$$
\mathrm{EI}=\text { Rate } \mathrm{EC}
$$

where:

$$
\begin{aligned}
& \mathrm{EI}=\text { indirect energy input, } \mathrm{Mcal} \mathrm{ha}{ }^{-1} \\
& \text { Rate }=\text { application rate of input, } \mathrm{kg} \mathrm{ha}^{-1} \\
& \mathrm{EC}=\text { energy coefficient of material used, } \mathrm{Mcal} \mathrm{kg}^{-1}
\end{aligned}
$$

The energy values of the following direct fossil fuel based energy inputs were taken from published literatures of Pimentel (1980); Pimentel et al. (1983); Cox and Atkins (1979); Mendoza (2005) and Egle and Mendoza (2013) as follows: for chemical fertilizer: $\mathrm{N}=24.54 \mathrm{Mcal} \mathrm{kg}^{-1} ; \mathrm{P}=2.30 \mathrm{Mcal} \mathrm{kg}^{-1} ; \mathrm{K}=1.60 \mathrm{Mcal} \mathrm{kg}^{-1}$; Pesticides $=99.9 \mathrm{Mcal} \mathrm{L}^{-1}$; Diesel oil $=10.109 \mathrm{Mcall}^{-1}$; and Machinery $=18 \mathrm{Mcal} \mathrm{kg}^{-1}$. For the indirect fossil fuel energy based inputs, labor energy value at $0.303 \mathrm{Mcal} \mathrm{hr}^{-1}$ (Kuether and Duff 1980 as cited by Mendoza 2005) and rice grain energy value at 
4.0 $\mathrm{Mcal} \mathrm{kg}^{-1}$ at $12 \%$ moisture content (Mendoza 2005). The labor energy input for each operation in rice production was estimated using the following:

$$
\mathrm{LE}=\frac{\mathrm{M} \times \mathrm{TIME}}{\mathrm{AREA}} \times \mathrm{LEF}
$$

where:

LE = Labor energy, Mcal ha $^{-1}$

M = Number of man days working hours

TIME $=$ operating time, h day $^{-1}$

AREA $=$ Operating area, ha

LEF $=$ labor energy factor, Mcal $^{-1}$

\section{Energy Productivity}

Energy productivity was computed by dividing the grain yield by the energy inputs from either indirect fossil fuel energy input (IFFEI) or total energy inputs (TEI) :

Energy productivity $_{\text {IFFE }}(\mathrm{kg}$ grain $/ \mathrm{LDOE})=\frac{\text { Grain yield }\left(\mathrm{kg} \mathrm{ha}^{-1}\right)}{\text { Total IFFEI in LDOE }}$

Energy productivity $_{\text {TEI }}(\mathrm{kg}$ grain $/ \mathrm{LDOE})=\frac{\text { Grain yield }\left(\mathrm{kg} \mathrm{ha}^{-1}\right)}{\text { TEI in LDOE }}$

where:

IFFEI $=$ indirect fossil fuel energy based

TEI $=$ total energy input

$\mathrm{LDOE}=$ liter diesel equivalent

\section{Energy Efficiency}

Energy efficiency (Ee) or energy balance was determined as the ratio of the energy output to the energy input. If the Ee, is greater than 1 , this means that the production system is gaining energy, otherwise it is losing energy.

$$
\mathrm{Ee}=\frac{\mathrm{e}_{\mathrm{o}}}{\mathrm{e}_{\mathrm{i}}}
$$

where:

$\mathrm{Ee}=$ energy efficiency or energy balance

$\mathrm{e}_{\mathrm{o}}=$ energy output, $\mathrm{MJ} \mathrm{ha}^{-1}$

$\mathrm{e}_{\mathrm{i}} \quad=$ energy input intensity, $\mathrm{MJ} \mathrm{ha}^{-1}$

\section{Energy Intensity}

Energy intensity for both IFFEI and TEI were calculated by dividing the total LDOE spent per unit quantity of grain produced as follows:

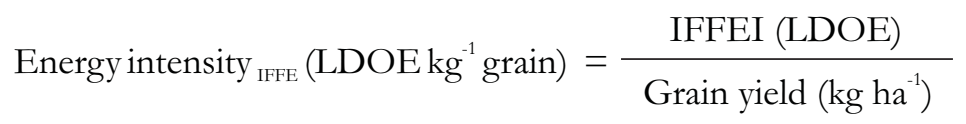


Energy intensity $_{\text {TEI }}\left(\mathrm{LDOE} \mathrm{kg}^{-1}\right.$ grain $)=\frac{\text { TEI }(\mathrm{LDOE})}{\text { Grain yield }\left(\mathrm{kg} \mathrm{ha}^{-1}\right)}$

To have a better grasp of the unit, the energy equivalent in MJ or Mcal was converted to liter diesel equivalent (LDOE) using the following:

$$
1 \mathrm{LDOE}=11.414 \mathrm{Mcal}, \quad 1 \mathrm{LDOE}=38.4 \mathrm{MJ}=38.4 \times 10^{6} \mathrm{~J}(\text { Mendoza 2008 })
$$

The averaged grain yields of two croppings were used as basis in the calculation of energy productivity, efficiency and intensity.

\section{RESULTS AND DISCUSSION}

\section{Grain Yield of PSB Rc18 Rice Grown in Various Nutrient Sources and Quantum Enhancers}

Figure 1 shows that grain yield of PSB Rc18 across 2 seasons was significantly highest when rice was applied with unenhanced composted cow manure $\left(\mathrm{T}_{6}\right)$. However, this was comparable to those applied with inorganic fertilizer at full rate $\left(\mathrm{T}_{2}\right)$ and at half dose combined with enhanced composted cow manure $\left(\mathrm{T}_{3}\right)$. This was followed by those applied with combined inorganic fertilizer (half dose) + quantum enhancers $\left(T_{4}\right.$ and $\left.T_{5}\right)$ and those applied with combined or sole organic nutrient sources or quantum enhancers and the control.

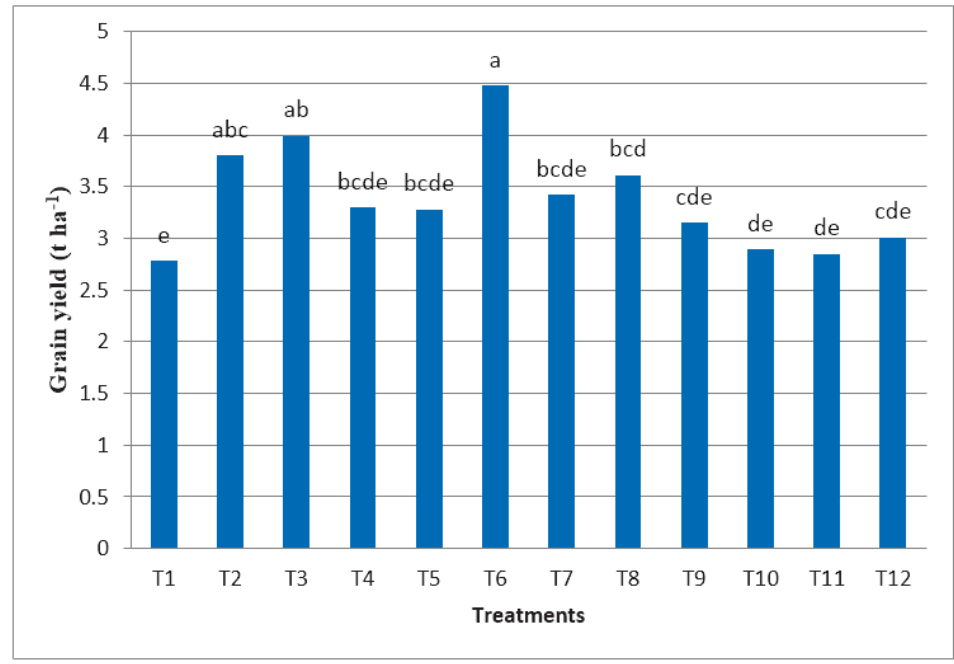

Fig. 1. Grain yield of lowland rice (var. PSB Rc18) across two seasons as influenced by various Legend: nutrient sources and quantum enhancers.

$\mathrm{T}_{1}$-control; $\mathrm{T}_{2}=70-60-30 \mathrm{~kg} \mathrm{~N}, \mathrm{P} 2 \mathrm{O} 5, \mathrm{~K} 2 \mathrm{O} \mathrm{ha}^{-1} ; \mathrm{T}_{3}=35-30-15 \mathrm{~kg} \mathrm{~N}, \mathrm{P} 2 \mathrm{O} 5, \mathrm{~K}_{2} \mathrm{O} \mathrm{ha}^{-1}+5 \mathrm{t} \mathrm{ha}^{-1}$ enhanced composted cow manure (ECCM); $\mathrm{T}_{4}=35-30-15 \mathrm{~kg} \mathrm{~N}, \mathrm{P} 2 \mathrm{O} 5, \mathrm{~K} 2 \mathrm{O} \mathrm{ha}^{-1}+\mathrm{BD} 500 ; \mathrm{T}_{5^{-}}$35-30-15 kg N, P2O5, $\mathrm{K} 2 \mathrm{O} \mathrm{ha}{ }^{-1}+30 \mathrm{~g} \mathrm{ha}^{-1}$ Agnihotra ash; $\mathrm{T}_{6}=5$ tons ha $^{-1}$ unenhanced composted cow manure; $\mathrm{T}_{7}=5 \mathrm{t} \mathrm{ha}^{-1}$ ECCM; $\mathrm{T}_{8}=5 \mathrm{t} \mathrm{ha}{ }^{-1} \mathrm{ECCM}+25 \mathrm{~g} \mathrm{ha}^{-1} \mathrm{BD} 500 ; \mathrm{T}_{9}=5 \mathrm{t} \mathrm{ha}^{-1} \mathrm{ECCM}+$ Agnihotra ash; $\mathrm{T}_{10}=4 \mathrm{~L} \mathrm{ha}^{-1} \mathrm{IMO} \mathrm{T}_{11}=25 \mathrm{~g}$ $\mathrm{ha}^{-1} \mathrm{BD} 500$; and $\mathrm{T}_{12}=30 \mathrm{~g} \mathrm{ha}^{-1}$ Agnihotra ash 
The application of unenhanced composted cow manure had significantly higher yields due to its markedly higher grain filling rates $\left(151.21 \mathrm{~kg} \mathrm{~d}^{-1}\right)$ comparable with those applied with the full rate of chemical fertilizer $\left(126.25 \mathrm{~kg} \mathrm{~d}^{-1}\right)$ and those with $1 / 2$ rate chemical fertilizer + ECCM $\left(134.60 \mathrm{~kg} \mathrm{~d}^{-1}\right)$ than the rest of the treatments. The least grain filling rate was noted with those applied with lone quantum enhancers and the control.

The higher amount of $\mathrm{N}$ supplied with unenhanced composted cow manure \& inorganic fertilizer could have attributed to this response. This conforms with the findings of Fageria (2006) and Yang and Zhang (2005) that high N rates usually delayed plant senescence thus enhanced grain filling which increased grain yield, better harvest index, and higher water use efficiency. Results of soil analysis after the second cropping also showed an increase in organic matter, nitrogen, and phosphorus content in plots applied with unenhanced composted cow manure. The higher microbial count in unenhanced composted cow manure could have also released growth promoting hormones which enhanced growth, development as well as yield production.

The superior contribution of various yield components namely: more productive tillers hill ${ }^{-1}$, longer panicles with denser grains per panicle, and heavier seed weight consequently resulted in appreciably higher grain yield of said treatment.

Energy Expenditures and Energy Productivity of PSB Rc18 Rice Grown in Various Nutrient Sources and Quantum Enhancers

The energy expenditures of the second crop with various nutrient sources at 1184.66 Mcal ha ${ }^{-1}$ or 103.79 liter diesel oil equivalent (LDOE) ha ${ }^{-1}$ were relatively higher compared to the first crop at 1127.24 Mcal ha ${ }^{-1}$ or 98.76 $\mathrm{LDOE} \mathrm{ha}^{-1}$ (Table 2). But due to significantly higher yield obtained during the second cropping, the energy productivity were $12 \%$ and $11 \%$ higher in both the direct fossil fuel energy based input (FFEI) and total energy input (TEI), respectively. This higher energy productivity may also mean lower energy use to produce a given quantity of rice.

Regardless of season, the total energy input for both croppings was highest with the application of the full rate of inorganic fertilizer $\left(225.74 \mathrm{LDOE} \mathrm{ha}^{-1}\right)$ or 2576.60 $\mathrm{Mcal} \mathrm{ha}^{-1}$ wherein 87\% was used for FFEI (195.70 LDOE ha ${ }^{-1}$ ) while 13\% (30.04 LDOE ha ${ }^{-1}$ ) was spent for the indirect fossil fuel energy inputs (IFFEI). This was followed by those treated with half rate of inorganic fertilizer in combination with either enhanced composted cow manure (144.10 LDOE ha 1 ) or with quantum enhancers of either BD 500 or agnihotra ash at 142.13-142.35 LDOE $\mathrm{ha}^{-1}$. Organic treatments of unenhanced or enhanced composted cow manure, with the latter applied alone or combined with quantum enhancers and IMO spent lower total energy ranging from 69.18-71.79 $\mathrm{LDOE} \mathrm{ha}^{-1}$. The untreated control and those with Quantum enhancers had the lowest energy expenditures ranging from 68.77-69.40 $\mathrm{LDOE} \mathrm{ha}^{-1}$.

Most of the energy expenses on direct fossil fuel energy input were generally spent for the manufacture of fertilizer materials which amounted to about $56 \%$ of the total energy cost (Fig. 2a). Fuel which was used to run machineries from production to post production activities ranked second which comprised $16 \%$ of the total energy cost. Of the three (3) fertilizer nutrients, nitrogen spent the highest 
energy cost which was $44 \%$ of the total energy input (Fig 2b). This made the inorganically-treated plots to be generally less productive in terms of energy use. This conforms to the findings of Bautista and Minowa (2010) that these inorganic inputs usually accounted the highest, reaching to about $80 \%$ of the total production inputs including seeds in all the farming systems tested. In sugarcane, $\mathrm{N}$ use from urea also accounted the highest at 93.7\% (Egle and Mendoza, 2013). The high energy expenses incurred with chemical fertilizer application made it the least energy efficient among the nutrient sources in terms of fossil fuel energy input and total energy input spent in the study. This also implies higher monetary requirement for the purchase of fossil fuel and oil. Although the inorganic treatment obtained a comparably high yield with those applied with unenhanced composted cow manure, its higher energy consumption led to the lower productivity of the system than the organic-treated plots. This further implies that the yield obtained with inorganic fertilizer application under the condition of the study did not compensate for the higher energy input it spent.

Table 2. Energy expenditures and energy productivity of lowland rice (var. PSB Rc18) across seasons as influenced by application of various organic nutrient sources and quantum enhancers.

\begin{tabular}{|c|c|c|c|c|c|c|}
\hline \multirow{3}{*}{ Treatments } & \multicolumn{4}{|c|}{ Energy Expenditures } & \multicolumn{2}{|c|}{ Energy Productivity } \\
\hline & \multirow{2}{*}{$\begin{array}{c}\text { FFEI } \\
\begin{array}{c}(\mathrm{LDOE} \\
\left.\mathrm{ha}^{-1}\right)\end{array}\end{array}$} & \multirow{2}{*}{$\begin{array}{c}\text { IFFEI } \\
\begin{array}{c}\text { (LDOE } \\
\left.\mathrm{ha}^{-1}\right)\end{array}\end{array}$} & \multicolumn{2}{|c|}{ TEI } & \multirow{2}{*}{$\begin{array}{c}\text { FFEI } \\
\text { (kg grain }\end{array}$} & \multirow{2}{*}{$\begin{array}{c}\text { TEI } \\
\left.\mathrm{LDOE}^{-1}\right)\end{array}$} \\
\hline & & & $\begin{array}{l}(\mathrm{LDOE} \\
\left.\mathrm{ha}^{-1}\right)\end{array}$ & $\begin{array}{c}\text { (Mcal } \\
\left.\mathrm{ha}^{-1}\right)\end{array}$ & & \\
\hline \multicolumn{7}{|l|}{ SEASON } \\
\hline Dry & 68.54 & 30.22 & 98.76 & 1127.24 & $60.68 \mathrm{~b}$ & $36.64 \mathrm{~b}$ \\
\hline Wet & 73.27 & 30.52 & 103.79 & 1184.66 & $68.00 \mathrm{a}$ & $40.72 \mathrm{a}$ \\
\hline Mean & 70.90 & 30.37 & 101.27 & 1155.95 & 64.32 & 38.66 \\
\hline \multicolumn{7}{|l|}{ NUTRIENT SOURCES } \\
\hline $\mathrm{T}_{1}=\operatorname{Control}(0-0-0)$ & 39.79 & 28.98 & 68.77 & 784.88 & $69.74 \mathrm{c}$ & $40.35 \mathrm{c}$ \\
\hline $\mathrm{T}_{2}=70-60-30 \mathrm{~kg} \mathrm{~N}, \mathrm{P}_{2} \mathrm{O}_{5}, \mathrm{~K}_{2} \mathrm{O} \mathrm{ha}^{-1}$ & 195.70 & 30.04 & 225.74 & 2575.60 & $19.91 \mathrm{~d}$ & $17.16 \mathrm{e}$ \\
\hline $\begin{array}{l}\mathrm{T}_{3}=35-30-15 \mathrm{~kg} \mathrm{~N}, \mathrm{P}_{2} \mathrm{O}_{5}, \mathrm{~K}_{2} \mathrm{O} \mathrm{ha}^{-1}+5 \mathrm{tha}^{-1} \\
\text { ECCM }\end{array}$ & 112.30 & 31.80 & 144.10 & 1644.76 & $35.53 \mathrm{~d}$ & $27.69 \mathrm{~d}$ \\
\hline $\begin{array}{l}\mathrm{T}_{4}=35-30-15 \mathrm{~kg} \mathrm{~N}, \mathrm{P}_{2} \mathrm{O}_{5}, \mathrm{~K}_{2} \mathrm{O} \mathrm{ha}^{-1}+25 \mathrm{~g} \mathrm{ha}^{-1} \\
\text { BD } 500\end{array}$ & 112.30 & 29.83 & 142.13 & 1622.27 & $29.36 \mathrm{~d}$ & $23.19 \mathrm{de}$ \\
\hline $\begin{array}{l}\mathrm{T}_{5}=35-30-15 \mathrm{~kg} \mathrm{~N}, \mathrm{P}_{2} \mathrm{O}_{5}, \mathrm{~K}_{2} \mathrm{O} \mathrm{ha}^{-1}+30 \mathrm{~g} \mathrm{ha}^{-1} \\
\text { AAsh }\end{array}$ & 112.30 & 30.05 & 142.35 & 1624.78 & $29.16 \mathrm{~d}$ & $23.01 \mathrm{de}$ \\
\hline $\mathrm{T}_{6}=5 \mathrm{tha}^{-1} \mathrm{UECM}$ & 39.78 & 30.16 & 69.94 & 798.30 & $112.58 \mathrm{a}$ & $64.04 \mathrm{a}$ \\
\hline $\mathrm{T}_{7}=5 \mathrm{tha}^{-1} \mathrm{ECM}$ & 39.78 & 31.37 & 71.15 & 812.11 & $86.01 \mathrm{bc}$ & $48.08 \mathrm{bc}$ \\
\hline $\mathrm{T}_{8}=5 \mathrm{tha}^{-1} \mathrm{ECM}+25 \mathrm{~g} \mathrm{ha}^{-1} \mathrm{BD} 500$ & 39.78 & 31.79 & 71.57 & 816.90 & $90.71 \mathrm{~b}$ & $50.42 \mathrm{~b}$ \\
\hline $\mathrm{T}_{9}=5 \mathrm{tha}^{-1} \mathrm{ECM}+30 \mathrm{~g} \mathrm{ha}^{-1}$ AAsh & 39.78 & 32.01 & 71.79 & 819.41 & $79.14 \mathrm{bc}$ & $43.87 \mathrm{bc}$ \\
\hline $\mathrm{T}_{10}=4 \mathrm{~L} \mathrm{ha}^{-1} \mathrm{IMO}$ & 39.78 & 29.40 & 69.18 & 789.62 & $72.65 \mathrm{c}$ & $41.77 \mathrm{bc}$ \\
\hline $\mathrm{T}_{11}=25 \mathrm{~g} \mathrm{ha}^{-1} \mathrm{BD} 500$ & 39.78 & 29.40 & 69.18 & 789.62 & $71.60 \mathrm{c}$ & $41.16 \mathrm{bc}$ \\
\hline $\mathrm{T}_{12}=30 \mathrm{~g} \mathrm{ha}^{-1}$ AAsh & 39.78 & 29.62 & 69.40 & 792.13 & $75.71 \mathrm{bc}$ & $43.39 \mathrm{bc}$ \\
\hline Mean & 70.90 & 30.37 & 101.27 & 1155.95 & 64.32 & 38.68 \\
\hline CV (\%) & & & & & 13.09 & 12.48 \\
\hline
\end{tabular}

Means in a column followed by a common letter or without designation are not significantly different at $5 \%$ level, HSD. Aash - agnihotra ash; BD- biodynamic ; ECCM - enhanced composted cow manure; UECCM unenhanced composted cow manure; IMO - indigenous microorganism 
Energy Efficiency and Energy Intensity of Rice Grown in Various Nutrient Sources and Quantum Enhancers

Energy efficiency (Ee) is the ratio of Mcal energy output ha ${ }^{-1}$ (grain yield) to Mcal energy input ha ${ }^{-1}$ suggesting for the amount of energy produced per unit energy used. Results indicated that the second cropping had significantly higher energy efficiency than the first cropping. Across croppings, markedly highest energy efficiency was obtained with application of unenhanced composted cow

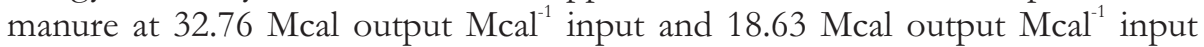
forFFEI and TEI, respectively (Table 3). This was followed by those supplied with other organic nutrient sources and quantum enhancers. The least was derived from the application of either pure inorganic fertilizers or when combined with enhanced composted cow manure or quantum enhancers. The result means that for every Mcal of energy used in unenhanced composted cow manure treatment, 32.76 and $18.63 \mathrm{Mcal}$ were produced which were almost 6 and 4 times more efficient as compared to the application of full rate inorganic fertilizer for FFEI and TEI, respectively. However, the former is just 1.37 and 1.53 times higher in terms of FFEI than the other organic sources of fertilizers (21.13-26.39 Mcal grain $\mathrm{Mcal}^{-1}$ energy) and quantum enhancers (20.83-22.02 Mcal grain $\mathrm{Mcal}^{-1}$ energy), respectively. The findings indicate that the use of organic-based inputs or quantum enhancers were more energy efficient than using inorganic fertilizers. Similarly, in some other crops, organic farming not only reduced energy consumption which in turn had higher energy productivity and efficiency but also mitigate environmental impacts due to lesser greenhouse gas emission as compared to the conventional practice (Gundogmos 2006, Ziesemer 2007, Kaltsas et al., 2007 and Kavargiris et al., 2009). The high energy expenses incurred with chemical fertilizer application $\left(T_{1}\right)$ made it the least energy efficient among the nutrient sources in terms of FFEI (5.79 Mcal output $\mathrm{Mcal}^{-1}$ input) and total energy input (5.00 Mcal output $\mathrm{Mcal}^{-1}$ input).

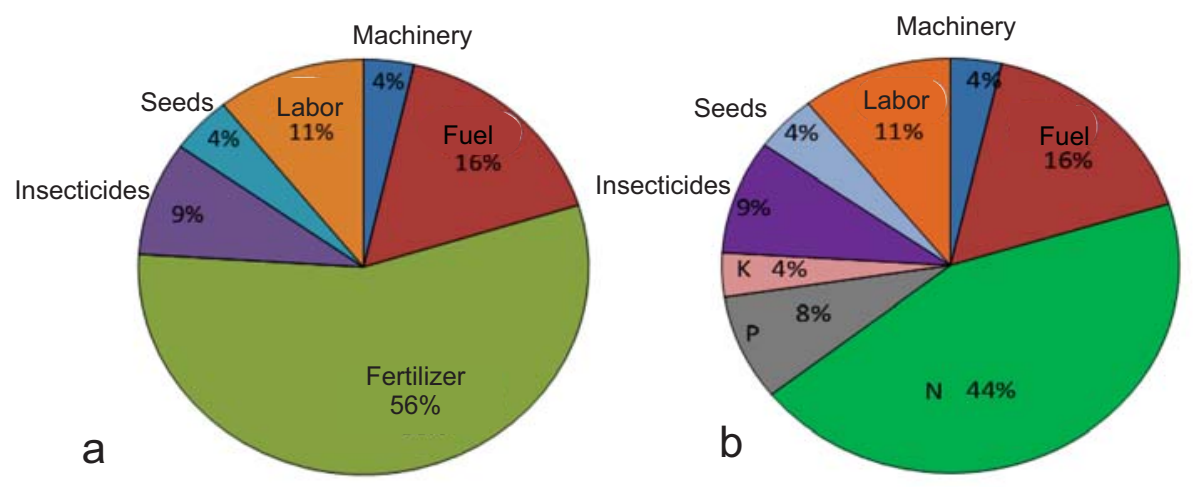

Figure 2. Energy utilization of production inputs (a) and fertilizer nutrients (b) in the conventional system.

Moreover, Karimi et al. (2008) reported that if energy is effectively used, this could mean financial savings and could leads to a sustainable agricultural production as fossil resources are preserved thus protect the environment. Application of full rate inorganic fertilizer also indicated that it was 2.35-3.50 times 


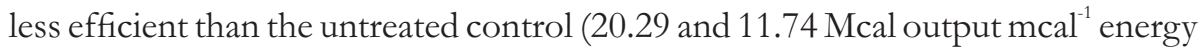
for FFEI and TEI, respectively) in account of its higher energy expenditure. Thus, to increase energy balance or efficiency, ways of reducing the use of high energy inputs especially chemical fertilizers should be looked into to minimize energy cost. This is on top of the detrimental effects it can cause the soil and environment through emission of $\mathrm{CO}_{2}$ or $\mathrm{N}_{2} \mathrm{O}$ into the atmosphere during its manufacturing process. Aguilera et al. (2013) stated that use of organic nutrient sources is better than synthetic fertilizers for they not only increase organic matter content of soil and help manage waste but can mitigate climatic changes by reducing $\mathrm{N}_{2} \mathrm{O}$ emissions by $23 \%$.

Energy intensity (Ei) is an estimate of how much energy in terms of liter diesel oil equivalent (LDOE) was used to produce a kilo or a ton of grain. Results showed that significantly higher energy intensity was observed during the first cropping (31.36 LDOE t $\mathrm{L}^{-1}$ grain) than the second cropping (29.31 $\mathrm{LDOE} \mathrm{t}^{-1}$ grain) (Table 3). This could be accounted to the significantly lower yield obtained during the former cropping (3.20 $\left.\mathrm{t} \mathrm{ha}^{-1}\right)$ despite its relatively lower energy expenditures. However averaged over croppings results revealed that application of full rate inorganic fertilizers had significantly the highest energy intensity of $0.053 \mathrm{LDOE}$ $\mathrm{kg}^{-1}$ grain and 60.89 LDOE $\mathrm{t}^{-1}$ grain for FFEI and TEI, respectively. This was followed by those applied with half rate of inorganic fertilizer + organic supplements and the least intense in terms of energy use was recorded from those treated with unenhanced composted cow manure and other sources of organic nutrients and quantum enhancers. This means that the inorganic treatment entails 3.82 times more energy intensity than the unenhanced composted cow manure treatment and 2.78 times than using the other organic amendments due to higher fuel and oil used to produce a ton of rice. This further implies that the energy spent to produce a ton of unmilled rice was reduced to as much as $64 \%$ with organic fertilization. These results conform to the findings of Mendoza (2005) that organic farming was not only the most energy efficient but also consumed the least amount of energy to produce a ton of unmilled rice. Application of quantum enhancer spent 24.42-25.16 LDOE ton $^{-1}$ grain which is $59 \%$ reduction in energy use over the inorganic treatments. The control had an energy intensity of $24.94 \mathrm{LDOE} \mathrm{ton}^{-1}$ grain or $0.014 \mathrm{LDOE} \mathrm{kg}^{-1}$ grain which is comparable to the organic treatments and is 2.44 times lower than the application of full rate of inorganic fertilizer.

The measure of energy intensity is more relevant nowadays that the cost of fuel and oil are steadily rising. There is a need therefore to look for a more energy efficient nutrient source that will not only enhance yield and energy balance of the production system but will also reduce production cost. As a consequence this will lessen the capital constraint of the farmer. Substituting high energy intensive inputs to least costly fertilizers will offer desirable characteristics to soil which could be of great advantage. Organic fertilizers especially if they are locally available can be cheaper source of nutrients as they no longer incur high energy cost for manufacturing, hauling, and transport. This consequently can reduced the financial burden of most resource-poor farmers. Humus in OM helps improve the physical as well as the chemical and biological properties of soils which increase its water holding and cation exchange capacities (Sciallaba and Lindenlauf 2010; Rimando et al., 2011). Results of soil analysis after the second cropping showed a relative increase in organic matter in organically treated plots which ranged from 3 
$4.29 \%$ over the initial determination with $3.30 \%$ only. With this premise, water and nutrient requirement of the crop may be reduced hence providing an added benefit to the farmer in terms of production cost.

A number of organic-based inputs are available as energy saving strategies that will reduce chemical fertilizer inputs (Karimi et al., 2008). Since cattle are often integrated into the farmers' crop production system in the Philippines, their waste can be a good and cheap source of organic fertilizer. Estimates had shown huge amount of excreta ranging from 6-13 t year $^{-1}$ or a $455 \mathrm{~kg}$ dairy cow produced about $36 \mathrm{~kg}$ or 1.3 cubic feet of manure a day (Pulhin et al., 1980; http://www. watersheds.org/farm/lawson.htm). With its use, substantial reduction in the purchase of inorganic fertilizers can be realized thus minimize energy and monetary expenditures. This further offers a more sustainable production system in the countryside.

Table 3. Energy efficiency and intensity of PSB Rc18 rice production across seasons as influenced by application of various organic nutrient sources and quantum enhancers.

\begin{tabular}{|c|c|c|c|c|}
\hline \multirow{3}{*}{ Treatments } & \multicolumn{2}{|c|}{$\begin{array}{c}\text { Energy } \\
\text { Efficiency }\end{array}$} & \multicolumn{2}{|c|}{$\begin{array}{l}\text { Energy } \\
\text { Intensity }\end{array}$} \\
\hline & FFEI & TEI & FFEI & TEI \\
\hline & \multicolumn{2}{|c|}{ Mcal grain Mcal energy ${ }^{-1}$} & $\begin{array}{l}\left(\mathrm{LDOE} \mathrm{kg}{ }^{-1}\right. \\
\text { grain) }\end{array}$ & $\begin{array}{c}\text { (LDOE t }{ }^{-1} \\
\text { grain) }\end{array}$ \\
\hline \multicolumn{5}{|l|}{ SEASON } \\
\hline Dry & $17.65 \mathrm{~b}$ & $10.66 \mathrm{~b}$ & 0.021 & $31.36 \mathrm{a}$ \\
\hline Wet & $19.78 \mathrm{a}$ & $11.84 \mathrm{a}$ & 0.021 & $29.31 \mathrm{~b}$ \\
\hline Mean & 18.71 & 11.25 & 0.021 & 30.33 \\
\hline \multicolumn{5}{|l|}{ NUTRIENT SOURCES } \\
\hline $\mathrm{T}_{1}=$ Control $(0-0-0)$ & $20.29 \mathrm{c}$ & $11.74 \mathrm{c}$ & $0.014 \mathrm{~d}$ & $24.94 \mathrm{c}$ \\
\hline $\mathrm{T}_{2}=70-60-30 \mathrm{~kg} \mathrm{~N}, \mathrm{P}_{2} \mathrm{O}_{5}, \mathrm{~K}_{2} \mathrm{O} \mathrm{ha}^{-1}$ & $5.79 \mathrm{~d}$ & $4.99 \mathrm{e}$ & $0.053 \mathrm{a}$ & $60.89 \mathrm{a}$ \\
\hline $\mathrm{T}_{3}=35-30-15 \mathrm{~kg} \mathrm{~N}, \mathrm{P}_{2} \mathrm{O}_{5}, \mathrm{~K}_{2} \mathrm{O} \mathrm{ha}^{-1}+5 \mathrm{tha}^{-1} \mathrm{ECCM}$ & $10.33 \mathrm{~d}$ & $8.06 \mathrm{~d}$ & $0.028 \mathrm{c}$ & $36.50 \mathrm{~b}$ \\
\hline $\mathrm{T}_{4}=35-30-15 \mathrm{~kg} \mathrm{~N}, \mathrm{P}_{2} \mathrm{O}_{5}, \mathrm{~K}_{2} \mathrm{O} \mathrm{ha}^{-1}+25 \mathrm{~g} \mathrm{ha}^{-1} \mathrm{BD} 500$ & $8.54 \mathrm{~d}$ & $6.75 \mathrm{de}$ & $0.035 \mathrm{~b}$ & $44.17 \mathrm{~b}$ \\
\hline $\mathrm{T}_{5}=35-30-15 \mathrm{~kg} \mathrm{~N}, \mathrm{P}_{2} \mathrm{O}_{5}, \mathrm{~K}_{2} \mathrm{O} \mathrm{ha}^{-1}+30 \mathrm{~g} \mathrm{ha}^{-1}$ AAsh & $8.48 \mathrm{~d}$ & $6.69 \mathrm{de}$ & $0.035 \mathrm{~b}$ & $43.96 \mathrm{~b}$ \\
\hline $\mathrm{T}_{6}=5 \mathrm{tha}^{-1} \mathrm{UECCM}$ & $32.75 \mathrm{a}$ & $18.63 \mathrm{a}$ & $0.009 \mathrm{~d}$ & $15.95 \mathrm{~d}$ \\
\hline $\mathrm{T}_{7}=5 \mathrm{tha}^{-1} \mathrm{ECCM}$ & $25.02 \mathrm{bc}$ & $13.99 \mathrm{bc}$ & $0.012 \mathrm{~d}$ & $21.00 \mathrm{~cd}$ \\
\hline $\mathrm{T}_{8}=5 \mathrm{th} \mathrm{ha}^{-1} \mathrm{ECCM}+25 \mathrm{~g} \mathrm{ha}^{-1} \mathrm{BD} 500$ & $26.39 \mathrm{~b}$ & $14.67 \mathrm{~b}$ & $0.011 \mathrm{~d}$ & $20.03 \mathrm{~cd}$ \\
\hline $\mathrm{T}_{9}=5 \mathrm{tha}^{-1} \mathrm{ECCM}+30 \mathrm{~g} \mathrm{ha}^{-1}$ AAsh & $23.01 \mathrm{bc}$ & $12.75 \mathrm{bc}$ & $0.013 \mathrm{~d}$ & $23.39 \mathrm{~cd}$ \\
\hline $\mathrm{T}_{10}=4 \mathrm{~L} \mathrm{ha}^{-1} \mathrm{IMO}$ & $21.13 \mathrm{c}$ & $12.15 \mathrm{bc}$ & $0.014 \mathrm{~d}$ & $24.42 \mathrm{c}$ \\
\hline $\mathrm{T}_{11}=25 \mathrm{~g} \mathrm{ha}^{-1} \mathrm{BD} 500$ & $20.83 \mathrm{c}$ & $11.97 \mathrm{bc}$ & $0.015 \mathrm{~d}$ & $25.16 \mathrm{c}$ \\
\hline $\mathrm{T}_{12}=30 \mathrm{~g} \mathrm{ha}^{-1}$ AAsh & $22.02 \mathrm{bc}$ & $12.61 \mathrm{bc}$ & $0.014 \mathrm{~d}$ & $23.58 \mathrm{~cd}$ \\
\hline Mean & 18.71 & 11.25 & 0.021 & 30.33 \\
\hline CV (\%) & 13.07 & 12.49 & 15.33 & 13.35 \\
\hline
\end{tabular}

Means in a column followed by a common letter or without designation are not significantly different at $5 \%$ level, HSD. Aash - agnihotra ash; BD- biodynamic ; ECCM - enhanced composted cow manure; UECCM unenhanced composted cow manure; IMO - indigenous microorganism 


\section{CONCLUSIONS}

Based on the results of the study, the following conclusions can be drawn:

1. The use of unenhanced composted cow manure produced significantly higher grain yield than the rest of the treatments though comparable with those applied with full dose inorganic fertilizers.

2. Application of organic fertilizers and quantum enhancers incurred lower energy expenditures than using inorganic fertilizers. This consequently resulted in markedly higher energy productivity than those applied with inorganic fertilizers and the untreated control with treatment on unenhanced composted cow manure as the most energy efficient and the least intense in terms of energy use. .

3. Application of quantum enhancers gave promise in increasing energy productivity and efficiency over the inorganic sources of nutrients, implying to be a valuable addition to organic farming.

\section{RECOMMENDATIONS}

It is recommended that follow up studies be done to reassess the energetics of lowland rice (PSB Rc18) treated with quantum enhancers and other nutrient sources in other agro-climatic conditions. There is also a need to verify the productivity and efficiency of quantum and other nutrient sources to other equally important upland crops.

\section{ACKNOWLEDGEMENT}

The first author would like to thank the Visayas State University and the Commission on Higher Education (CHED)-Higher Education Development Project-Faculty Development Program (HEDP-FDP) for the scholarship and the Agricultural Training Institute-EHRDP for the additional dissertation support in the conduct of this research.

\section{REFERENCES}

AgUiLERA, E., L. LASSALETTA, A.S. COBENA, J. GARNIER and A. VALLEJO. 2013. The potential of organic fertilizers and water management to reduce $\mathrm{n}_{2} \mathrm{O}$ emissions in Mediterranean climate cropping systems. A Review. Agriculture, Ecosystems and Environment. 164:32-52.

ANGELES, S. M. 2008. Seed invigoration of rice (Oryza sativa L.) and mungbean (Vigna radiate L.R. Wilczek) through hydration-dehydration with potentization and agnihotra ash. Unpublished B.S. Thesis. University of the Philippines. Los Baños, Laguna, Philippines. 64 pp.

BANAEIAN, N., M. ZANGENEH and M. OMID. 2010. Energy use efficiency for walnut producers using Data Envelopment Analysis (DEA). Australian Journal of Crop Science 4(5): 359-362.

BAUTISTA E.G. and T. MINOWA. 2010. Analysis of the energy for different rice production systems in the Philippines. Pbillip. Agric. Scientist. 93(3):346-357. 
BLENGINI G. A. and M. BUSTO. 2009. The life cycle of rice: LCA of alternative agric-food chain management systems in Vercelli, Italy. Jour. of Environmental Management. 90:1512-1522.

BOCHARI-GEVAO, S.M., W.I. WAN ISHAK, A.Y. AZMI, and C.W. CHAN. 2005. Analysis of energy consumption in lowland rice-based cropping system of Malaysia. Retrieved May 8, 2008. Songklanakarin J. Sc. Technol. 27(4):819826.

COX G.W. and M.D. ATKINS. 1979. Agricultural Ecology, An Analysis Of World Food Production Systems. W.H. Freeman and Co.,San Francisco.720pp.

DON BOSCO DIOCESAN YOUTH CENTER, INC. UNDATED. Don Bosco Integrated Programs and Initiatives for Sustainable Development through Sustainable Agriculture. An Introductory Course on the Basic Principles and Practices of Biodynamic Agriculture. Don Bosco Diocesan Youth Center, Inc. Batasan, Makilala, Cotabato. 75 pp.

EGLE, R.B. and T.C. MENDOZA.2013. Energy use of sugarcane (Saccharum Officinarum L.) grown in various nutrient supply options. Philippine Journal of Crop Science. 38(1): 43-51.

FAO.2010. Asia Pacific Food Situation Update. FAO, Rome.

FERNANDEZ, P.G. 2000. Compendium on Sustainable Perspective and Strategiesof Advocates and Practitioners in the Philippines. DAR-UNDP SardicProgramme. Department of Agrarian Reform, Diliman, Quezon City, Philippines. 678pp.

FERNANDEZ, P.G. 2001. Organic Seed: Implications for Sustainable Agriculture.Inaugural SEARCA Professorial Chair Lecture. Department of Agronomy, College of Agriculture, University of the Philippines Los Baños, College, Laguna. Philippines. 162pp.

GUNDOGMUS, E. 2006. Energy use on organic farming: a comparative analysis on organic versus conventional apricot production on small holdings in Turkey. Energy Conversion and Management. 47:3351-3359.

HERRING, H. 2006. Energy efficiency-a critical view. Energy. 31: 10-20.

JAYASREE, p. and A. GEORGE. 2006. Do biodynamic practices influence yield quality and economics of cultivation of chilli (Capsicum annum L.)? Journal of Tropical Agriculture. 44(1-2):68-70.

JING, Q. 2007. Improving resource use efficiency in rice-based cropping systems: experimentation and modeling. Ph.D.Dissertation. Waningen University, Wanengin, The Netherlands. 145pp.

KALTSAS, A.M., A.P. MAMOLOS, C.A. TSATSARELIS, G.D. NANOS, and K.L. KALBURTJI. 2007. Energy budget in organic and conventional olive groves. Agriculture, Ecosystems and Environment. 122:243-251.

KARIMI, M., A. RAJABI POUR, A. TABATABAEEFAR and A. BORGHEI. 2008. Energyanalysis of sugarcane production in plant farms: a case study in debel khazai agro-industry in Iran. American-Eurasian Journal of Agriculture \& Environmental Science. 4: 165-171.

KAVARGIRIS, S.E., A.P. MAMOLOS, C.A. TSATSARELIS, A.E. NIKOLAIDOU and K.L. KALBURTJI. 2009. Energy resources' utilization in organic and conventional vineyards: energy flow, greenhouse gas emissionsand biofuel production. Biomass and Bioenergy. 33:1239-1250. 
MENDOZA, T.C. and R. SAMSON. 2002. The energy costs of sugar production in the Philippine context. Philippine Journal of Crop Science. 27(2):17-26.

MENDOZA, T.C. 2005. An energy-based analyis of organic, low external input sustainable agriculture (leisa) and conventional rice production in the Philippines. The Philippine Agricultural Scientist. 88(3):257-267.

MENDOZA, T.C. 2007. The energetics of ethanol production and its implications. Asia Life Sciences. 16(2):115-138.

MENDOZA, T.C. 2008. Why food prices increase and what can be done? Phil. Jour. of Crop Science. 33:87-101.

MENDOZA, T.C. 2010. Organic agriculture: The logical sequence to modern chemical agriculture in the Philippine context. A Discussion Paper. Annals of Tropical Research. 32(1):112-129.

NASSIRI, S. M. and S. SINGH. 2009. Study on energy use efficiency for paddy crop using data envelopment Analysis (dea) technique. Applied Energy. 86:1320-1325.

PERLAS, N.G. 1993. The Seven Dimensions Of Sustainable Agriculture. Paper Presented at the Second Asian Development Forum held at Xavier University, Cagayan De Oro City, Philippines. February 22-27, 1993.159-175.

PIMENTEL, D. (Ed) 1980. Handbook of Energy Utilization in Agriculture. CRC Press. Boca Raton, Florida. 474 pp.

PIMENTEL, D., G. BERARDI and S. FAST. 1983. Energy efficiency of farming systems: organic and conventional agriculture. Agriculture, Ecosystem and Environment. 9:359-372.

PULHIN, R.S.V. and Z.H. SHEHADEH. 1980. Integrated AgricultureAquaculture Farming Systems. Proceedings of the ICLARM-SEARCA Conference on Integrated Agriculture-Aquaculture Farming Systems, Manila, Philippines. 6-9 August 1979.259pp.

RAHMAN, S. and B.K. BARMON. 2012. Energy productivity and efficiency of the "gher" (prawn-rice) farming in Bangladesh. Energy.43:293-300.

REGANOLD, J.P. 1995. Soil quality, profitability of Biodynamic and conventional farming systems: A Review. Organic Farming and Biodynamic Agricultural Training Resource Book. 10:1:64-75.

RIMANDO, T.J., T.H. BORROMEO, B. M SALAZAR, P.C. STA. CRUZ, A.G. LALUSIN, M.F.O. MERCADO and A.M.A. MAGNAYE.2011. Fundamentals of Crop Science. UPLB, Los Banos, Laguna. 185pp.

SCILLABBA, N. EH. and M. LINDENLAUF. 2010. Organic agriculture and climate change. Renewable Agriculture and Food Systems: 25(2):158-169.

SINGH S. M.P. SINGH, and P. BAKHSHI. 1990. Unit energy consumption for paddy-wheat rotation. Energy Convers Manage. 30:121.

STRAPATSA, A.V., G.D. NANOS, and C.A. TSATSARELIS. 2006. Energy flow for integrated apple production in Greece. Agric. Ecosystems Environment. 116: 176-180.

STEINER, R. 2005. What Is Biodynamics? A Way To Heal And Revitalize The Earth. Steiner Books. USA. 190 pp.

VALDEZ, R.E. and P.G. FERNANDEZ. 2008. Productivity and seed quality of rice (Oryza sativa L.) cultivars grown under synthetic, organic fertilizer and biodynamic farming practices. Phil. Crop Science Journal. 32:49-62. 
WILDFEUER, S. 2006. What is Biodynamics. Biodynamic Farming and Gardening Association. http://www.biodynamics.com/biodynamics.html.

ZAMORA, O.B. 1996. The sustainable agriculture framework: concepts, misconceptions and barriers to adoption and opportunities. pp.7-37. In S.S. Go, V.A. Quiton, W.T. Alesna, S.P. Sandoval, E.G. Cagasan and C.R. Arceña(ed), Sourcebook on Curriculum Revision for the Integration of Sustainable Agriculture Concepts. SEARCA-VISCA-ACAP, Philippines. $135 \mathrm{pp}$.

ZIESEMER, J. 2007. Energy use in organic food systems. Natural Resources Management And Environment. Dept. Food and Agriculture Organization of the United Nations. Rome. 28 pp.

http://www.indexmundi.com/philippines/population_growth_rate.html.Philip pines Population growth rate 2009. Accessed 03 November 2010.

http://www.watersheds.org/farm/lawson.htm. Cow manure facts. Accessed 05 January, 2011. 